\title{
Determination of honey quality in the context of physico-chemical and microbiological data in Bosnia and Herzegovina
}

\author{
Viktor Landeka $^{1 *}$, Harun Kurtagić ${ }^{1}$, Jovica Pažin ${ }^{1}$, Edita Sarić $^{1}$ \\ ${ }^{1}$ Federal Institute for Agriculture Sarajevo, Butmir road 40, 71210 Ilidža, BiH \\ * Corresponding author: viktorlandeka@gmail.com
}

\begin{abstract}
The aim of this study was to examine the correlation of the obtained results and the overall quality of honey by testing some physico-chemical and microbiological parameters of honey quality. The quality of honey is determined by it's organoleptic, biological, physicochemical and microbiological properties. The purpose of this study was to evaluate the relationship between physico-chemical properties and microbiological properties and for the purpose of determining honey quality.

Samples were submitted by honey producers in Bosnia and Herzegovina (B\&H) in 2018. A total of 14 samples of various categories of honey from different geographical areas of $B \& H$ were taken for testing. Microbiological analysis was performed for recommended microorganisms: aerobic mesophilic bacteria, bacteria from the family Enterobacteriaceae, sulfite-reducing clostridia and yeasts and molds from the guidelines for microbiological criteria for food in B\&H (FSA B\&H 2013), which is adapted to EU regulations. Of the total number of samples examined, all complied with the regulations. In 50\% of the examined honeys, the presence of predominant microorganisms within the permissible deviation was recorded. The presence of yeasts and molds was found in 35\% of honey samples at a concentration of 10 to 100 cfulg, while the presence of aerobic mesophilic bacteria was recorded in $15 \%$ of the sample over a concentration of $100 \mathrm{cfu} / \mathrm{g}$ and in them $15 \%$ at a concentration of 10 to 100 $c f u / g$, Enterobacteriaceae and sulfito-reducing clostridia were not isolated and counted. From the physico-chemical parameters, the following were examined: the content of reducing sugars, sucrose and total sugars, electrical conductivity, the content of mineral substances, the content of free acids and the content of moisture (dry matter). All physico-chemical parameters are in accordance with the required quality of the Rulebook on honey quality (Official Gazette of B\&H, 37/09).

Given the very diverse complexity of honey composition, it is very difficult to say the actual source of microbiological activity of the honey samples tested in this study. Considering that the parameters of possible antimicrobial activity have not been examined and considering the obtained results, it is not possible to say with certainty whether and which of the tested physicochemical parameters affects the total microbiological activity of honey. The microbiological presence in the samples indicates the necessity of production, handling and storage of honey, according to the rules of good hygienic practice.
\end{abstract}

\section{Keywords: honey, microbiological analysis, physico-chemical analysis, content, quality}

\section{Introduction}

Natural ingredients in honey, such as phenols, flavonoids, aromatic acids and others, are responsible for a wide range of antimicrobial (antibacterial, antifungal and antiviral) effects. Honey generally has two basic groups of mechanisms by which it exerts antibacterial activity. The first group includes mechanisms (osmolarity, viscosity, pH value) of antibacterial activity based on its physico-chemical properties (Abeshu and Geleta, 2016; Kiš et al., 2019). The second group of mechanisms of antibacterial activity of honey is based on the chemical substances that are present in it (hydrogen peroxide, methylglyoxal and antimicrobial peptide bee defensin-1). Hydrogen peroxide is one of the most important antimicrobial components of honey along with methylglyoxal and the antimicrobial peptide bee defensin-1 (Gobin et al., 2014). Natural honey shows great variability in antimicrobial activity against pathogenic bacteria, because the composition of active ingredients in plants depends on various factors, especially on plant species and chemo type, and on climatic conditions (Gradvol et al., 2015). Despite a number of inhibitory factors, some microorganisms are still able to survive in honey and can be transmitted through consumption to consumers. Honey can be contaminated by microorganisms through primary and secondary sources. Primary sources (during harvest) include pollen, digestive apparatus of bees, dust, air, soil and nectar which is very difficult to control in natural conditions. Secondary sources (after harvest), are packaging filling, handling, during feeding, cross-contamination, equipment and storage (Borum Ayse E., et al 2018). Bacillus, Clostridium, Penicillium, Mucor, Saccharomyces, Schizosaccharomyces and Torula are microorganisms of interest for contamination in honey.

Sulfite-reducing clostridia is an indicator of microorganisms, whose presence in honey is evidence of contamination. The presence of Clostridium spp spores is especially dangerous for infants and young children. Pediatric botulism is mainly caused by the consumption of honey contaminated with C. botulinum (Erkan M.E., et al. 2015). The interest is mainly based on anti-pathogen activities and its use as a natural remedy (Gomes et al., 2010). Today, there is much evidence of the clinical effectiveness of honey in wound healing therapy. The conclusions are quite unanimous regarding the fact that honey therapy is effective, safe and has an outstanding price-benefit ratio. However, not all authors agree on whether honey therapy gives better results than conventional therapy (Bijelić et al., 2010). Health research on honey is mostly focused on bacterial contamination. As a source of free amino acids, sugars and minerals, honey is a suitable medium for the development of yeasts and molds, especially due to inappropriate handling during production and unfavorable storage conditions. (Carvalho et al., 2005; Kiš et al., 2019). The quality of honey depends on the influence of various factors, primarily on factors related to geographical origin, seasonal production conditions, type of honey plants, processing conditions, method of packaging and method of storage of honey (Marghitas et al., 2009). The composition of honey is strongly related to its geographical origin, which is related to the area from which the honey originates (Kurtagić et al., 2016). Due to its complex chemical composition, honey is an unfavorable medium for the growth of microorganisms. High sugar concentration, low $\mathrm{pH}$ value, low water activity, the presence of hydrogen peroxide and other 
specific substances in honey, have an inhibitory effect on the growth and reproduction of microorganisms. Microorganisms that can survive in these conditions in honey are primarily yeasts and molds and sporoform bacteria (Gradvol et al., 2015). Aerobic mesophilic bacteria are common causes of food spoilage and are used as an indicator of age and reduced microbiological quality. They are part of the normal flora of the digestive system of bees, and honey contamination can also occur during the production and storage of products (Kacániová et al., 2009, Kiš et al., 2019). The aim of this study was to examine the correlation of the obtained results and the overall quality of honey by testing some physicochemical and microbiological parameters of honey quality. The quality of honey is determined by its organoleptic, biological, physicochemical and microbiological properties. The purpose of this study was to evaluate the relationship between physico-chemical properties and microbiological properties and for the purpose of determining honey quality.

\section{Material and methods}

During 2018, 14 honey samples were collected from the area of six cantons of Bosnia and Herzegovina (B\&H), mainly of continental geographical origin; Una - Sana Canton - 6 samples, Tuzla Canton - 1 sample, Zenica Doboj Canton - 1 sample, Sarajevo Canton - 3 samples and the Bosnian Podrinje Canton - 2 samples, and one from the sub-Mediterranean region (Herzegovina-Neretva Canton - 1 sample). Samples were delivered in sterile glass containers in which they were stored at room temperature until the moment of testing. First, microbiological and then physicochemical testing was performed. Samples were collected from honey producers from the above areas at the time of vomiting.

\section{Chemicals, accessories and equipment}

All chemicals used were p.a. purity. The producers of the chemicals are Carlo Erba and Fisher Chemicals. Equipment, accessories and other resources were used within the laboratory.

\section{Test methods}

Physico-chemical tests were performed according to the standard methods from the Ordinance on methods for control of honey and other bee products (Official Gazette of B\&H, 2009).

Determination of sugar was performed by the Luff-Schoorl method. The method is based on the principle that under certain conditions, reducing sugar (natural invert) converts $\mathrm{Cu} 2+$ ions into $\mathrm{Cu}+$ ions. Unused amount of $\mathrm{Cu} 2+$ ions is re-titrated with standard sodium thiosulfate solution. From the difference between the consumption for the blank test and the test, the amount of sugar can be seen from the table, which shows the correlation between the consumption of the reagent and the amount of sugar.

The determination of sucrose was performed according to the Ordinance on methods for the control of honey and other bee products (Annex II, section $\mathrm{D}$ ), and is calculated as the difference in the content of reducing

Table 1. Microbiological methods of isolation and identification sugars before and after hydrolysis, multiplied by a factor of 0.95 .

Free acidity was determined by titration with a standard solution of sodium hydroxide with phenolphthalein as an indicator. The moisture content was determined gravimetrically by drying at $100^{\circ} \mathrm{C}-105^{\circ} \mathrm{C}$.

The electrical conductivity at $20^{\circ} \mathrm{C}$ was determined using a conductometer (Eutech Instruments Con 110), using an aqueous solution of honey (the amount of honey equivalent to $20 \mathrm{~g}$ of dry matter of honey dissolved in $100 \mathrm{ml}$ of distilled water).

Microbiological tests were conducted according to the guidelines on microbiological criteria for food in B\&H (FSA B\&H, 2013). Microbiological analyzes were performed on aerobic mesophilic bacteria, Enterobacteriaceae, sulfite-reducing clostridia, and yeasts and molds. Chemical manufacturers are Himedia, Merck. Standard ISO microbiological methods of growing on rootstocks were used for counting and identification of microorganisms in honey (Table 1). All analyzes were performed in the laboratory of the Federal Institute of Agriculture Sarajevo, which is accredited according to ISO standard 17025 .

\section{Results and discussion}

\section{Results of microbiological testing}

During microbiological analyzes of honey from a total of 14 samples, the presence of aerobic mesophilic bacteria as well as the presence of yeasts and molds was determined in $50 \%$ of them, in samples $790,824,852$, $868,872,881,888$ (Table 2). All samples meet the recommendations of the Guidelines on Microbiological Criteria for Food in B\&H (FSA B\&H, 2013), which is adapted to EU regulations. In $50 \%$ of different types of honey, the presence of the number of predominant microorganisms was within the permitted limits $(790,824,852,868,872,881,888)$.

Of the total number of tested samples, the presence of yeasts and molds was found in 5 of them in a concentration of 10 to $102 \mathrm{cfu} / \mathrm{g}$ (sample codes: $824,852,868,872,881$ ) while the presence of aerobic mesophilic bacteria was recorded in 2 samples or $15 \%$ of the sample over a concentration of $102 \mathrm{cfu} / \mathrm{g}$ (sample codes: 852,888 ) and in two samples at a concentration of 10 to $102 \mathrm{cfu} / \mathrm{g}$ (sample codes: 790,872 ). The results are presented in such way that the finding for aerobic mesophilic bacteria in honey in accordance with the provisions of the regulations is presented as negative $(<10 \mathrm{cfu} / \mathrm{g})$, acceptable (up to $103-104 \mathrm{cfu} / \mathrm{g}$ ) or unsatisfactory $(>104 \mathrm{cfu} / \mathrm{g})$, for yeasts and molds as negative $(<10$ $\mathrm{cfu} / \mathrm{g})$, acceptable (10-102 cfu/g) and unsatisfactory (> $102 \mathrm{cfu} / \mathrm{g})$. Enterobacteriaceae and sulfite-reducing clostridia were not isolated nor were their numbers determined in this study (Table 2).

The obtained results of microbiological parameters are correlated with studies conducted across Europe (Kacániová et al., 2009; Rozanska, 2011; Felsociova et al., 2012; Sinacori et al., 2014; Gradvol et al., 2015; Erkan M.E.,el.al 2015; Kiš et al., 2019.

In our study, the obtained results are correlated with research conducted by a number of researchers across Europe. Thus (Gradvol et al., 2015),

\begin{tabular}{|c|c|c|c|}
\hline Microorganisms & Nutrient medium & Incubation conditions & Method \\
\hline Aerobic mesophilic bacteria & Plate Count agar (PCA-agar) & $30^{\circ} \mathrm{C}$ during $72 \mathrm{~h}$ & $\begin{array}{l}\text { BAS EN ISO } \\
4833-1: 2014\end{array}$ \\
\hline Enterobacteriaceae & $\begin{array}{l}\text { Violet Red } \\
\text { Bile Glucose agar (VRBG-agar) }\end{array}$ & $37^{\circ} \mathrm{C}$ during $24 \pm 2 \mathrm{~h}$ & $\begin{array}{l}\text { BAS EN ISO } \\
21528-2: 2018\end{array}$ \\
\hline Sulfite-reducing clostridia & $\begin{array}{l}\text { Iron sulphate agar } \\
\text { (ISA-agar) }\end{array}$ & $37^{\circ} \mathrm{C}$ during $24-48 \mathrm{~h}$ & BAS EN ISO 15213:2008 \\
\hline Yeasts and molds & $\begin{array}{l}\text { Dichloran } 18 \% \\
\text { mass fraction glycerol agar (DG } 18 \\
\text { agar ) }\end{array}$ & $25^{\circ} \mathrm{C}$ during 7 days & $\begin{array}{l}\text { BAS EN ISO } \\
\text { 21527-2:2009 }\end{array}$ \\
\hline
\end{tabular}




\section{Table 2. Results od microbiological testing}

\begin{tabular}{|c|c|c|c|c|c|}
\hline \multirow[t]{2}{*}{$\begin{array}{l}\text { Sample } \\
\text { code }\end{array}$} & \multirow[t]{2}{*}{ Honey tipe } & \multicolumn{4}{|l|}{ Microorganisms } \\
\hline & & $\begin{array}{l}\text { Aerobic mesophilic } \\
\text { bacteria in } 10 \mathrm{~g}\end{array}$ & $\begin{array}{l}\text { Enterobacteriacae } \\
\text { in } 10 \mathrm{~g}\end{array}$ & $\begin{array}{l}\text { Sulfite-reducing } \\
\text { clostridia } \\
\text { in } 10 \mathrm{~g}\end{array}$ & $\begin{array}{l}\text { Yeasts an molds } \\
\text { in } 10 \mathrm{~g}\end{array}$ \\
\hline 761 & honeydew & $<10 \mathrm{cfu} / \mathrm{g}$ & $<10 \mathrm{cfu} / \mathrm{g}$ & $<10 \mathrm{cfu} / \mathrm{g}$ & $<10 \mathrm{cfu} / \mathrm{g}$ \\
\hline 790 & chestnut & $1 \times 102 \mathrm{cfu} / \mathrm{g}$ & $<10 \mathrm{cfu} / \mathrm{g}$ & $<10 \mathrm{cfu} / \mathrm{g}$ & $<10 \mathrm{cfu} / \mathrm{g}$ \\
\hline 824 & forest & $<10 \mathrm{cfu} / \mathrm{g}$ & $<10 \mathrm{cfu} / \mathrm{g}$ & $<10 \mathrm{cfu} / \mathrm{g}$ & $1 \times 10^{2} \mathrm{cfu} / \mathrm{g}$ \\
\hline 825 & acacia & $<10 \mathrm{cfu} / \mathrm{g}$ & $<10 \mathrm{cfu} / \mathrm{g}$ & $<10 \mathrm{cfu} / \mathrm{g}$ & $<10 \mathrm{cfu} / \mathrm{g}$ \\
\hline 842 & acacia & $<10 \mathrm{cfu} / \mathrm{g}$ & $<10 \mathrm{cfu} / \mathrm{g}$ & $<10 \mathrm{cfu} / \mathrm{g}$ & $<10 \mathrm{cfu} / \mathrm{g}$ \\
\hline 852 & meadow & $2,7 \times 10^{3} \mathrm{cfu} / \mathrm{g}$ & $<10 \mathrm{cfu} / \mathrm{g}$ & $<10 \mathrm{cfu} / \mathrm{g}$ & $1 \times 10^{2} \mathrm{cfu} / \mathrm{g}$ \\
\hline 868 & acacia & $<10 \mathrm{cfu} / \mathrm{g}$ & $<10 \mathrm{cfu} / \mathrm{g}$ & $<10 \mathrm{cfu} / \mathrm{g}$ & $1 \times 10^{2} \mathrm{cfu} / \mathrm{g}$ \\
\hline 872 & acacia & $1 \times 10^{2} \mathrm{cfu} / \mathrm{g}$ & $<10 \mathrm{cfu} / \mathrm{g}$ & $<10 \mathrm{cfu} / \mathrm{g}$ & $1 \times 10^{2} \mathrm{cfu} / \mathrm{g}$ \\
\hline 881 & chestnut & $<10 \mathrm{cfu} / \mathrm{g}$ & $<10 \mathrm{cfu} / \mathrm{g}$ & $<10 \mathrm{cfu} / \mathrm{g}$ & $1 \times 10^{2} \mathrm{cfu} / \mathrm{g}$ \\
\hline 885 & floral & $<10 \mathrm{cfu} / \mathrm{g}$ & $<10 \mathrm{cfu} / \mathrm{g}$ & $<10 \mathrm{cfu} / \mathrm{g}$ & $<10 \mathrm{cfu} / \mathrm{g}$ \\
\hline 886 & forest & $<10 \mathrm{cfu} / \mathrm{g}$ & $<10 \mathrm{cfu} / \mathrm{g}$ & $<10 \mathrm{cfu} / \mathrm{g}$ & $<10 \mathrm{cfu} / \mathrm{g}$ \\
\hline 887 & chestnut & $<10 \mathrm{cfu} / \mathrm{g}$ & $<10 \mathrm{cfu} / \mathrm{g}$ & $<10 \mathrm{cfu} / \mathrm{g}$ & $<10 \mathrm{cfu} / \mathrm{g}$ \\
\hline 888 & meadow & $5 \times 10^{2} \mathrm{cfu} / \mathrm{g}$ & $<10 \mathrm{cfu} / \mathrm{g}$ & $<10 \mathrm{cfu} / \mathrm{g}$ & $<10 \mathrm{cfu} / \mathrm{g}$ \\
\hline 893 & floral & $<10 \mathrm{cfu} / \mathrm{g}$ & $<10 \mathrm{cfu} / \mathrm{g}$ & $<10 \mathrm{cfu} / \mathrm{g}$ & $<10 \mathrm{cfu} / \mathrm{g}$ \\
\hline
\end{tabular}

in its large study conducted in Croatia on 72 samples did not find the bacteria Enterobacteriaceae and Clostridium spp. In honey samples, aerobic mesophilic bacteria were found in all types of honey within acceptable limits.

This authors states that chestnut honey showed the strongest inhibitory effect on the tested bacterial species, while the lowest inhibition was shown by linden honey.

In Italy (Sinacori et al., 2014) in their study of 38 samples indicate the presence of yeasts and molds in 3 samples, but no higher concentrations than $102 \mathrm{cfu} / \mathrm{g}$, as Enterobacteriaceae were found in only two samples. The presence of clostridia was found in 15 samples, with the highest estimated value ( $0.92 \mathrm{MPN} / \mathrm{g})$. In a study conducted on 40 samples from the area of northwestern Croatia in 2018., the presence of the number of aerobic mesophilic bacteria and the number of yeasts and molds was determined in 16 samples (or $40 \%$ ) of samples. The presence of the number of aerobic mesophilic bacteria below the concentration of $103 \mathrm{cfu} / \mathrm{g}$ was found in 13 samples (or $32.5 \%$ ), above the prescribed maximum concentration was found in 3 (or 7.5\%) samples, while concentrations above $103 \mathrm{cfu} / \mathrm{g}$, the presence of yeast was determined in 10 (or 25\%) samples of honey, while in 11 (or 27.5\%) samples the presence of the number of molds in the concentration from 10 to 102 $\mathrm{cfu} / \mathrm{g}$ was determined. Simultaneous contamination with yeasts and molds was found in 5 (or 12.5\%) samples (Kiš et al., 2019). Likewise, the characterization of molds and yeasts from honey samples from Poland showed that the yeast and mold concentration was less than $102 \mathrm{cfu} / \mathrm{g}$ (Felsociova et al., 2012). In a large study in Poland on 245 samples of different plant species of Polish honey have different levels of bacteria and low levels of yeast and mold. The samples showed different levels of microbiological contamination. The total number of aerobic bacteria varied from $1.0 \times 101 \mathrm{cfu} / \mathrm{g}$ to 7.5 x $104 \mathrm{cfu} / \mathrm{g}$. Salmonella spp. was not detected in any of the 25 honey samples. Anaerobic bacteria form spores in $14.3 \%$ to $36.4 \%$ of samples, depending on the type of honey. The number of yeasts and molds was low and only occasionally exceeded 1.0 x $102 \mathrm{cfu} / \mathrm{g}$ (Rozanska, 2011). Bacteria, such as coliforms, enterococci, bacilli, as well as fungi belonging to the genera Penicillium, Cladosporium, and Alteraria have been identified in Slovak honey (Kacániová et al., 2009).

In a study in Turkey on 50 samples collected from all over the country in retail, 43 of them were found to have the number of aerobic mesophilic bacteria in a concentration of $1 \times 101-9.6 \times 106 \mathrm{cfu} / \mathrm{g}$, the number of yeasts was found in 26 samples in a concentration of $1 \times 102-1.2 \times 103$ $\mathrm{cfu} / \mathrm{g}$ and mold in 46 concentration samples of $7.4 \times 103-1.4 \times 105 \mathrm{cfu} / \mathrm{g}$. In the same study, B.cereus with a concentration of $1 \times 101-1.2 \times 102 \mathrm{cfu} / \mathrm{g}$ was found in 4 samples (Erkan et al., 2015).

\section{Results of physico-chemical testing}

According to the national regulation of $\mathrm{B} \& \mathrm{H}$ as well as international regulations (Official Gazette of B\&H, 2009; EU Council Directive, 2002), the results of all tested physico-chemical parameters (Table 3) of honey samples were in accordance with the criteria (Table 4). Some previous studies of physico-chemical parameters have shown similar results, however, they recorded wrong declaration of honey type (Kurtagić and Skenderović, 2017). Total dry matter content in honey samples (Table 3, Table 5); forest honey samples $(761,824,886)$, acacia samples $(825,842,868,872)$, chestnut samples $(790,881,887)$, meadow samples $(852,888)$ and flower honey samples $(885,893)$, have a dry matter content in the range of $80.8 \%$ (chestnut honey) to $85.1 \%$ (forest honey).

All three chestnut samples have an approximate dry matter content, satisfactory other parameters and a relatively low free acid content. No sucrose was detected in sample 790. Acacia samples have similar characteristics except for sample 825 , which has slightly higher dry matter content. All other tested samples, regardless of geographical or biological origin, have similar and satisfactory characteristics of physico-chemical parameters.

Dry matter content in honey samples other than sugar (Table 5): When observing the dry matter content in honey samples other than sugar, it can be seen that it ranges from $0.5 \%$ (sample 881 - chestnut) to $19.8 \%$ ( sample 761 - forest honey). Forest honey samples showed the highest content $(761,886)$ and the lowest content was found in chestnut honey (881).

The sample of flower honey (893) had eight times higher content of dry matter components in honey than in sample 881 (chestnut honey). Approximate value of dry matter content other than sugar in the sample of forest honey 761 had the sample 886 (forest honey). Other tested honey samples had relatively approximate contents of other dry matter 
Table 3. Results of physico-chemical testing

\begin{tabular}{|c|c|c|c|c|c|c|c|c|c|}
\hline \multirow[t]{2}{*}{$\begin{array}{l}\text { Sample } \\
\text { code }\end{array}$} & \multicolumn{3}{|c|}{ Sugar $(\%)$} & \multirow[t]{2}{*}{$\begin{array}{c}\text { Dry matter } \\
(\%)\end{array}$} & \multirow[t]{2}{*}{$\begin{array}{c}\text { Moisture } \\
(\%)\end{array}$} & \multirow{2}{*}{$\begin{array}{c}\text { Electrical } \\
\text { conductivity } \\
\left(\mathrm{mScm}^{-1}\right)\end{array}$} & \multirow[t]{2}{*}{$\begin{array}{c}\text { Mineral matter } \\
(\%)\end{array}$} & \multirow[t]{2}{*}{$\begin{array}{c}\text { Free acid } \\
\left(\mathrm{mmolkg}^{-1}\right)\end{array}$} & \multirow[t]{2}{*}{ Honey type } \\
\hline & Reducing & Total & Sucrose & & & & & & \\
\hline 761 & 57,8 & 62,2 & 4,2 & 82,0 & 18,0 & 1,11 & 0,55 & 39 & forest \\
\hline 790 & 75,4 & 75,4 & 0,0 & 81,1 & 18,9 & 1,11 & 0,56 & 18 & chestnut \\
\hline 824 & 63,3 & 73,5 & 9,7 & 82,9 & 17,1 & 0,97 & 0,49 & 38 & forest \\
\hline 825 & 74,6 & 76,9 & 2,2 & 84,3 & 15,7 & 0,21 & 0,11 & 18 & acacia \\
\hline 842 & 75,2 & 76,2 & 1,0 & 83,6 & 16,4 & 0,22 & 0,11 & 16 & acacia \\
\hline 852 & 74,1 & 75,7 & 1,5 & 82,1 & 17,9 & 0,30 & 0,15 & 30 & meadow \\
\hline 868 & 70,9 & 73,6 & 2,6 & 82,4 & 17,6 & 0,29 & 0,14 & 26 & acacia \\
\hline 872 & 72,5 & 73,5 & 1,0 & 81,7 & 18,3 & 0,50 & 0,25 & 21 & acacia \\
\hline 881 & 76,4 & 80,3 & 3,7 & 80,8 & 19,2 & 1,34 & 0,67 & 13 & chestnut \\
\hline 885 & 74,2 & 75,3 & 1,1 & 83,0 & 17,0 & 1,06 & 0,53 & 23 & floral \\
\hline 886 & 63,3 & 67,1 & 3,6 & 85,1 & 14,9 & 1,46 & 0,73 & 26 & forest \\
\hline 887 & 72,5 & 73,1 & 0,5 & 82,2 & 17,8 & 1,77 & 0,89 & 13 & chestnut \\
\hline 888 & 70,9 & 73,6 & 2,6 & 83,1 & 16,9 & 0,60 & 0,30 & 20 & meadow \\
\hline 893 & 77,5 & 78,6 & 1,1 & 82,7 & 17,3 & 0,32 & 0,16 & 35 & floral \\
\hline average & 71,3 & 73,9 & 2,5 & 82,6 & 17,4 & 0,8 & 0,4 & 24,0 & $\begin{array}{l}\text { All sam- } \\
\text { ples }\end{array}$ \\
\hline stdev & 5,8 & 4,6 & 2,4 & 1,2 & 1,2 & 0,5 & 0,3 & 8,7 & \\
\hline average & 74,8 & 76,3 & 1,4 & 81,4 & 18,6 & 1,4 & 0,7 & 14,7 & chesnut \\
\hline stdev & 2,0 & 3,7 & 2,0 & 0,7 & 0,7 & 0,3 & 0,2 & 2,9 & \\
\hline average & 61,4 & 67,6 & 5,8 & 83,3 & 16,7 & 1,2 & 0,6 & 34,3 & forest \\
\hline stdev & 3,2 & 5,7 & 3,4 & 1,6 & 1,6 & 0,3 & 0,1 & 7,2 & \\
\hline average & 73,3 & 75,1 & 1,7 & 83,0 & 17,0 & 0,3 & 0,2 & 20,3 & acacia \\
\hline stdev & 2,0 & 1,8 & 0,8 & 1,2 & 1,2 & 0,1 & 0,1 & 4,3 & \\
\hline average & 72,5 & 74,6 & 2,0 & 82,6 & 17,4 & 0,5 & 0,2 & 25,0 & meadow \\
\hline stdev & 2,3 & 1,5 & 0,7 & 0,7 & 0,7 & 0,2 & 0,1 & 7,1 & \\
\hline average & 75,8 & 76,9 & 1,1 & 82,8 & 17,2 & 0,7 & 0,3 & 29,0 & floral \\
\hline stdev & 2,3 & 2,3 & 0,0 & 0,2 & 0,2 & 0,5 & 0,3 & 8,5 & \\
\hline
\end{tabular}

Table 4. Review of limit values of physico-chemical parameters of honey quality

\begin{tabular}{|c|c|c|c|c|c|c|c|}
\hline P Parameter: & $\begin{array}{c}\text { Total sugars } \\
(\%)\end{array}$ & $\begin{array}{c}\text { Reducing } \\
\text { sugars }(\%)\end{array}$ & $\begin{array}{c}\text { Sucrose } \\
(\%)\end{array}$ & $\begin{array}{l}\text { Free acidity } \\
(\mathrm{mmol} / \mathrm{kg})\end{array}$ & $\begin{array}{l}\text { Moisture } \\
(\%)\end{array}$ & $\begin{array}{c}\text { Electrical } \\
\text { conductivity } \\
(\mathrm{mS} / \mathrm{cm})\end{array}$ & $\begin{array}{c}\text { Mineral content } \\
(\%)\end{array}$ \\
\hline $\begin{array}{l}\text { Limit values } \\
\text { according to } \\
\text { Regulation } \\
\text { [9]: }\end{array}$ & Not given & $\begin{array}{l}\text { Nectar honey: } \\
>60 \% \\
\text { Honeydew, } \\
\text { mixed honey: } \\
>45 \%\end{array}$ & $\begin{array}{l}\text { Generally: } \\
<5 \% \\
\text { Acacia and } \\
\text { honeysuckle: } \\
<10 \%\end{array}$ & $\begin{array}{l}\text { Generally: } \\
<50 \mathrm{mmol} / \mathrm{kg} \\
\text { Industrial } \\
\text { honey: } \\
<80 \mathrm{mmol} / \mathrm{kg}\end{array}$ & $\begin{array}{l}\text { Generally: } \\
<20 \% \\
\text { Heather and } \\
\text { industrial honey: } \\
<23 \% \\
\text { Industrial heather } \\
\text { honey: } \\
<25 \%\end{array}$ & $\begin{array}{l}\text { Nectar honey: } \\
<0,8 \mathrm{mS} / \mathrm{cm} \\
\text { Honeysuckle } \\
\text { and chestnut } \\
\text { honey: } \\
>0,8 \mathrm{mS} / \mathrm{cm}\end{array}$ & $\begin{array}{l}\text { Generally: } \\
<0,6 \% \\
\text { Honeydew: } \\
<1,2 \%\end{array}$ \\
\hline
\end{tabular}


Table 5. Content of all other components of dry matter in honey except sugar

\begin{tabular}{|l|l|l|l|l|l|l|l|l|l|l|l|l|l|l|l|}
\hline Sample mark & 761 & 790 & 824 & 825 & 842 & 852 & 868 & 872 & 881 & 885 & 886 & 887 & 888 & 893 & \\
\hline $\begin{array}{l}\text { Dry matter - sugar } \\
(\%)\end{array}$ & 19,8 & 5,7 & 9,4 & 7,4 & 7,4 & 6,4 & 8,8 & 8,2 & 0,5 & 7,7 & 18 & 9,1 & 9,5 & 4,1 & 8,7 \\
\hline
\end{tabular}

- medium value

in honey other than sugar and are relatively close to the medium value of $8.7 \%$ (Table 5 ). Statistically speaking, expressed over average and standard deviation, all data are in accordance with regulations regardless of the type of the honey, but there are some specific ones (Table 3). The highest amount of sugar was found in floral type of honey, but it's very close to chesnut where the highest amount of sucrose was determined. The best data fit of sugar are in acacia (4 samples) and meadow (3 samples). In all types of samples the amount of dry matter are similar, but it was highest in forest honey, moisture content was similar but the highest was in chestnut, while free acid was the highest in forest honey, then in floral type of honey (Table 3).

Samples 824, 852, 868, 872, 881 contained yeasts and molds. Samples 852 and 872 contained, in addition to yeasts and molds an aerobic mesophilic bacteria. Sample 888 contained only aerobic mesophilic bacteria. In all other samples all tested microorganisms were $<10$ $\mathrm{cfu} / \mathrm{g}$. It is evident that the obtained results of microbiological and physicochemical tests cannot lead to a direct correlation (Table 2, Table $3)$. Namely, in all samples in which aerobic microorganisms were found, yeasts and molds $(824,852,868$ and 872$)$ have a total dry matter content between 82 and $83 \%$, which does not differ significantly from the results in samples in which no microorganisms were found (Table 3). In the samples with the highest dry matter content except sugars 761 and 886 (Table 3), the tested microorganisms were not detected, although it could theoretically be expected. Thus, it can be said that according to the obtained results, the content of total dry matter or dry matter other than sugar is not in direct correlation with the presence or absence of tested microorganisms.

Samples of meadow honey 852 and 888 (Tables 2 and 3) in which an increased number of aerobic mesophilic bacteria was recorded in the permitted concentration, and it's tested chemical parameters are all within the permissible deviation. The microbiological presence in the samples indicates possible external contamination and the necessity of production according to the rules of good hygienic practice with the systematic implementation of microbiological control of honey.

Given the very diverse complexity of honey composition, it's microbiological activities are very different from both the same species and different types of honey (Zafar H.I., 2014), so it is very difficult to say the actual source of microbiological activity of the tested honey samples in this study. Since the parameters of possible antimicrobial activity were not examined (Zafar H.I., 2014; Gobin et al., 2014; Kiš et al., 2019), and considering the obtained results, it is not possible to say with certainty whether and which of the tested physico-chemical parameters affects the overall microbiological activity of honey. This study did not take into account climatic conditions and environmental conditions, as well as anthropogenic factors that are very important for the microbiological properties of honey.

\section{Conclusions}

Honey has antimicrobial and inhibitory potential against pathogenic bacteria, spore-forming bacteria, aerobic mesophilic bacteria, molds and yeasts. However, some microorganisms have the ability to survive in honey, which affects the stability and quality of the product. Care must be taken when handling honey during production, handling, vomiting, and storage of honey and the application of good hygiene practice with the application of preventive procedures to control the production process in order to reduce public health risk for the general population. In this study, no direct correlation was found between physico-chemical results and microbiological results in terms of microbiological quality of honey. Namely, the obtained data show that the water content (ie total dry matter), as well as the content of dry matter without sugar do not have a direct correlation in microbiological activity to the content of tested microorganisms (aerobic mesophilic bacteria, Enterobacteria, sulfite-reducing clostridia, yeasts and molds). Of all the tested physicochemical parameters (content of reducing sugars, sucrose and total sugars, electrical conductivity, mineral content, content of free acids and moisture content), none can be directly correlated with microbiological results. According to the obtained test results, it can be concluded that the tested samples meet the quality regulations.

\section{References}

Abeshu M.A., Geleta B. (2016) Medicinal Uses of Honey. Biology and Medicine, 8 (2) 2 - 7.

BAS EN ISO 15213:2008. Microbiology of food and animal feeding stuffs - Horizontal method for the enumeration of sulphite - reducing bacteria under anaerobic conditions. Institute for standardization of Bosnia and Herzegovina, 2008, p. $1-6$.

BAS EN ISO 21527-2:2009. Microbiology of food and animal feeding stuffs - Horizontal method for the enumeration of yeasts and molds - Part 2: Colony - count technique in products with an activity less than or equal to 0.95. Institute for standardization of Bosnia and Herzegovina, 2009 , p. 1 - 9. BAS EN ISO 21528-2:2018. Microbiology of the food chain - Horizontal method for the detection and enterobacteriaceae - Part 2: Procedure for colony counting. Institute for standardization of Bosnia and Herzegovina, 2018, p. 1 - 19.

BAS EN ISO 4833-1:2014. Microbiology of the food chain - Horizontal method for the determination of microorganisms - Part 1: Determination of colony count at $30^{\circ} \mathrm{C}$ by substrate irrigation. Institute for standardization of Bosnia and Herzegovina, 2014, p. $1-12$.

Bijelić N., Biljan D., Rostohar Bijelić B. (2010) The use of honey in modern wound therapy. Medicinski Vjesnik, 42 (1-2) 65 - 70.

Borum Ayse E., Mesut E.G. (2018) Microbiological contamination of honeys from different sources in Turkey. The Journal of Apicultural Science, 62 (1) $89-96$.

Carvalho C. M., Rocha A., Estevinho M. L. F., Choupina A. (2005) Identification of honey yeast species based on RFLP analysis of the ITS region. Ciência e Tecnologia de Alimentos, $511-17$.

Council Directive (2002) 2001/110/EC of 20 December 2001 relating to honey Official Journal of the European Communities 10, p. 47 - 52.

Erkan M.E., Vural A., Guran H.S., Durmusoglu H. (2015) Microbiological investigation of honey collected from Şırnak province of Turkey. Journal of the Hellenic Veterinary Medical Society, 66 (1) $22-26$.

Felsociova S., Kacaniova M., Hleba L., Petrova J., Pavelkova A., Dzugan M. (2012) Microscopic fungi isolated from Polish honey. Journal of Microbiology, Biotechnology and Food Sciences, 21040 - 1049.

Gobin I., Vučković D., Lušić D. (2014) Antibacterial properties of honey. Medicina Fluminensis, 50 (2) 150 - 157. 
Gomes S., Dias LG., Moreira L.L., Rodrigues P., Estevinho L. (2010) Physico-chemical, microbiological and antimicrobial properties of commercial honeys from Portugal, Food and Chemical Toxicology, 48 (2) 544 - 558.

Gradvol V., Atlaban N., Lenart L., Pavlović H. (2015) Microbiological quality and inhibitory potential of selected Croatian apiary honeys, Croatian Journal of Food Science and Technology, 7 (2) 40 - 46.

Guidelines on Microbiological Criteria for Food of B\&H (2013) Food Safety Agency of Bosnia and Herzegovina; 4.3. Honey and products paragraph 4.3.1., p. 31.

Kacániová M., Pavlicová S., Haščík P., Kociubinski G., Kñazovická V., Sudzina M. P. (2009) Microbial communities in bees, pollen and honey from Slovakia. Acta Microbiologica et Immunologica Hungarica, 56285 - 295.

Kiš M., Furmeg S., Jaki Tkalec V., Sokolović J., Zadravec M., Majnarić D., Cvetnić Ž. (2019) Microbiological analysis of honey with mold identification. Veterinary Practice 50 (2) $107-113$.

Kurtagić H., Memić M., Barudanović S. (2016) Determination of type of honey produced in different climatic regions of Bosnia and Herzegovina. International Journal of Environmental Science and Technology, 13, $2721-2730$.

Kurtagić H., Skenderović E. (2017) Determining the quality of honey produced in Bosnia and Herzegovina (B\&H) on the basis of physical and chemical data, Proceedings and abstracts from the Second congress on beekeeping and bee products. Association for Nutrition and Dietetics, With Food to Health. Tuzla, Bosnia and Herzegovina, 2 (1) p. 97 - 102.

Marghitas A.L., Stanciu O.G., Dezmirean D.S., Bobis O., Popescu O., Bogdanov S., Campos M.G. (2009) In vitro antioxidant capacity of honeybeecollected pollen of selected floral origin harvested from Romania. Food Chemistry, $115878-883$.

Official Gazette of Bosnia and Herzegovina (2009) Rulebook on Methods for Control of Honey and Other Bee Products of B\&H, No. 37/09, p. 333 -341 .

Rozanska H. (2011) Microbiological quality of polish honey. Bulletin of the Veterinary Institute in Pulawy, $55443-445$.

Sinacori M., Francesca N., Alfonzo A., Cruciata M., Sannino C., Settanni L. (2014) Cultivable microorganisms associated with honeys of different geographical and botanical origin. Food Microbiology, 38 284-294.

Zafar H.I. (2014) Antimicrobial properties of honey. American Journal of Therapeutics, 21304 - 323. 